\title{
Kurumsal İletişimde Sosyal Medya Kullanımının Kadın Voleybol Spor Kulübü Açısından İncelenmesi
}

\author{
Investigation of the Use of Social Media in Corporate Communication \\ from the Perspective of Women's Volleyball Sports Club
}

\author{
Erman MUTLU* \\ Mehmet Mustafa YORULMAZLAR ${ }^{* *}$ iD
}

\begin{abstract}
Öz
\end{abstract}
Bu çalışmada, Eczacıbaşı VitrA Spor Kulübünün kurumsal iletişim aracı olarak kullandığı resmi sosyal medya platformları olan Facebook, Twitter, Instagram ve YouTube hesapları üzerinden elde edilen verilerin sayfa görünümü, hesap içeriği, paylaşım türü ve hesapların kullanım düzeyleri açısından incelenerek yorumlanması amaçlanmıştır. Çalışmanın çıkış noktası, Eczacıbaşı VitrA Spor Kulübünün 2019 yılı dünya kulüpler sıralamalarında ilk 5 (beş) içerisinde yer almış olmasıdır. Nitel özelliğe sahip bu araştırmada belgesel tarama modeli kullanılmıştır. Araştırmanın evreni, ülkemizde faaliyet gösteren tüm kadın voleybol spor kulüpleridir. Bu bağlamda, kulübün resmi sosyal medya hesaplarının açılış tarihlerinden 19 Mayıs 2020 tarihine kadar olan süreç araştırmanın örneklemini oluşturmuştur. Elde edilen veriler betimsel analiz yöntemiyle çözümlenmiştir. Çalışma neticesinde, Eczacıbaşı VitrA Spor Kulübünün sosyal medyayı etkin bir şekilde kullandığı, kadın voleybolunda sosyal medyayı dünyada en aktif kullanan üç spor kulübü içerisinde yer aldığı, bununla birlikte hesaplarının genel görünümü ile bazı paylaşım türlerinde eksiklikler olduğu ve paydaşlarıyla etkileşiminin yeterli düzeyde olmadığı saptanmıştır. Çalışmadaki verilerin Eczacıbaşı VitrA Spor Kulübü ile diğer spor kulüplerinin sosyal medya mecrasındaki iletişim noksanlıklarını giderebilmelerine ve paydaşlarıyla daha etkili bir iletişim kurabilmelerine yardımcı olacağı düşünülmektedir.

Anahtar Kelimeler: Eczacıbaşı VitrA Spor Kulübü, kurumsal iletişim, sosyal medya, voleybol.

\begin{abstract}
In this study, it was aimed to examine and interpret the data obtained through the official social media platforms like Facebook, Twitter, Instagram and YouTube used by Eczacıbaşı VitrA Sports Club as corporate communication tools. The collected data were evaluated in terms of page view, account content, types of sharing and account usage levels. Eczacıbaşı VitrA Sports Club’s 2019 world club ranking (top 5)

* Yüksek lisans, Marmara Üniversitesi, Sağlık Bilimleri Enstitüsü, erman.mutlu@windowslive.com, ORCID: 0000-0002-7525-1360

* Doç. Dr. Marmara Üniversitesi, Spor Bilimleri Fakültesi, mehmet.yorulmazlar@marmara.edu.tr, ORCID: 0000-0002-1051-0798
\end{abstract}


was chosen as a starting point of the study. From the qualitative research methods, documentary survey model was used in the study. Universe of the study was the all women's volleyball teams operating in Turkey. In this context, the period starting from the opening dates of the clubs' official social media accounts to 19 May 2020 constituted the sample of the study. The obtained data were analyzed with descriptive analysis method. It was concluded that Eczacıbaşı VitrA Sports Club used the social media effectively and they were among the three sports clubs that use social media actively in women's volleyball, but there were some deficiencies in the general view of their accounts and some types of sharing and their interaction with their stakeholders. It is thought that the data obtained from the study will help Eczacıbaşı VitrA Sports Club and other sports clubs to overcome their communication deficiencies in their social media channels and to establish more effective communication with their stakeholders.

Keywords: Eczacıbaşı VitrA Sports Club, corporate communication, social media, volleyball.

\section{GíRIŞ}

Geride bıraktığımızyüzyılın ikinciyarısından itibaren hızla büyüyen bilişim veiletişim teknolojilerinin etkileşimiyle sonucunun kestirilmesinin çok güç olduğu bir dönemin başlangıcı ortaya çıkmıştır. $\mathrm{Bu}$ etkileşimin bir sonucu da dev bir paylaşım platformu olan sosyal medya olgusunun insanoğlunun hayatına girmesidir (Kahraman, 2010).

Sosyal medya, geniş kitlelere anında ulaşma ve bütün insanlarla çevrim içi iletişim kurabilme olanağ 1 sunmaktadır (Vural ve Bat, 2010). Spor kulüplerinin yeni medya türünün bu özelliklerinin farkına varması; bilinirliği ve marka imajını artırmak, taraftar ile bağları kuvvetlendirmek, kulüp hakkında bilgi paylaşmak, reklam ve pazarlama stratejileri geliştirmek, sponsor bulmak vb. önemli birçok imkânı beraberinde getirmektedir. Sosyal medya kullanımı ile elde edilen bu imkânları keşfeden spor kulüplerinin amaçlarına ulaşmak için sosyal medya platformlarını kullanmaları kaçınılmaz hâle gelmiştir (Barutçu ve Tomaş, 2013).

Eczacıbaşı VitrA Spor Kulübü, elde ettiği başarılarla ülkemizin tanınırlığını artıran ve ülkemiz insanını olumlu anlamda etkileyen bir kulüptür. Sosyal medyanın da toplum ile örgütler üzerindeki etkisi ve sağladığı faydalar aşikârdır. Dolayısıyla bu çalışmanın özgün yapısı ve ortaya koyduğu verilerin hem Eczacıbaşı VitrA Spor Kulübünün sosyal medya kullanımını değerlendirmek hem de bu konuda gelecekte yapılacak çalışmalara katkı sağlamak açısından önem arz ettiği düşünülmektedir.

Kurumsal iletişim; kurum kimliğinin, kültürünün, felsefesinin, değerlerinin ilgili çevrelere doğru ve eksiksiz bir şekilde aktarılmasını içeren iletişim sürecidir (Bat, 2012). Bir başka ifadeyle kurumsal iletişim; bir kurumun müşterileri, tedarikçileri ve tüm paydaşlarıyla doğrudan kurduğu iletişimdir (Johan ve Noor, 2013; Özel, 2014).

Şirket içi ve dışında gerçekleşen diyaloglarda iletişimin kalitesi büyük bir önem kazanmıştır. Söz konusu iletişim kalitesinin sağlanması için çeşitli kurumsal iletişim araçlarından yararlanılmaktadır (Herand ve Çalışır, 2014). Bu araçlar yazıll, sözlü, görsel-işitsel ve elektronik iletişim araçları olarak sınıflandırılmaktadır (Peltekoğlu, 2004). Bu çalışmada, kurumsal iletişim aracı olan elektronik iletişim araçlarından sosyal paylaşım ağları/platformları kullanılacaktır. 
Yeni iletişim araçlarının gelişmesi ve yaygınlaşmasıyla birlikte kurum ve kuruluşlar internet ortamını ürün, mal ve hizmet bilgilerini tüketicilere iletmek, onlarla iletişime geçmek, onların ihtiyaç ile isteklerini anlamak ve bu doğrultuda satış stratejisi geliştirmek, doğrudan satı̧̧ yapmak gibi birçok farklı amaçla kullanmaktadır (Akyüz, 2017).

Spor kulüplerinin temel paydaşlarının taraftarlar, kulüp üyeleri, yayıncı kuruluşlar, finansal kuruluşlar, yerel yönetimler, topluluklar, ulusal ve uluslararası yasa koyuculardan oluştuğu düşünüldüğünde kulüplerin işleyişleri içerisinde bu paydaşlar ile ilişki kurmak ve bu ilişkiyi yönetmek büyük önem taşımaktadır (Binns, 2003).

Spor kulüplerinde kurumsal iletişim kavramı; kulübün hedef kitlesine yönelik tüm iletişim faaliyetlerinin amaçlı, planlı, etkin, uyumlu ve bilinçli bir şekilde yürütülmesi olarak tanımlanabilmektedir (Ayan Gürsoy, 2019).

Sosyal medya; Web 2.0 teknolojileri üzerine kurulmuş, sosyal etkileşime imkân veren, kişilerin bilgi ve deneyimlerini çevrim içi olarak çevreleriyle paylaşmalarını sağlayan web sitelerinden oluşmaktadır (Fox, 2009).

Sosyal medya; insanlara ve kurumlara hür bir tartışma ortamı doğuran, bireylerin kendi aralarında ve örgütlerle olan bildirişimini sağlayan bir araçtır. Bunun yanı sıra hedeflenen gruplarla çift yönlü iletişim gerçekleştirmek, kurum imajını yükseltilmek, pazarlama ve halkla ilişkiler faaliyetlerinde bulunmak gibi olanaklar sunmaktadır (Yamamoto ve Şekeroğlu, 2014). Sosyal medya araçlarının spor kulüplerine sunduğu firsatlar sadece sporcular ve taraftarlar ile sınırlı kalmamaktadır. Markalar ve sponsorlar gibi diğer tüm paydaşlar ile yeni iletişim alanı içerisinde iletişim kurulmasını da sağlamaktadır (Özçağlayan, 2012). Bu fırsatı iyi değerlendirebilen kulüplerin bir adım öne çıkması beklenmektedir.

Kurumsal iletişim aracı olarak kullanılan sosyal medya hesapları ile ilgili literatürde yer alan çalışmalar ayrıntılı bir şekilde incelenmiştir. Bu inceleme sonucunda kadın voleybol spor kulüplerinin sosyal medya hesapları ile ilgili bir çalışmanın yapılmadığı gözlemlenmiştir. Bu çalışma, alanındaki ilk çalışmadır. Bu konuda yapılacak farklı çalışmalara yol gösterecek olması sebebiyle, çalışma sonucunda ortaya çıkan verilerin ehemmiyet arz ettiği düşünülmektedir.

Literatürdeki araştırmalardan elde edilen veriler ışı̆̆ında şu sorulara yanıtlar aranacaktır:

- Eczacıbaşı VitrA Spor Kulübünün sosyal medyayı kullanımı (genel görünüm, hesap içeriği, paylaşım türü) ne düzeydedir?

- Ulusal ve uluslararası kadın voleybol spor kulüpleri ile karşılaştıııldığında sosyal medya hesapları görünümü nasıldır?

Bu çalışmada, Eczacıbaşı VitrA Spor Kulübünün kurumsal iletişim aracı olarak kullandığı sosyal medya platformları olan Facebook, Twitter, Instagram ve YouTube hesapları üzerinden elde 
edilen verilerin sayfa görünümü, paylaşım içerikleri ve kullanım düzeyleri açısından incelenerek yorumlanması amaçlanmıştır.

\section{YÖNTEM}

Araştırmanın Modeli: Nitel araştırma desenine sahip bu çalışmada belgesel tarama modeli kullanılmıştır. Belgesel tarama; belli bir amaca yönelik olarak kaynakları bulma, okuma, not alma ve değerlendirme basamaklarından oluşur (Karasar, 2010). Nitel araştırmalarda doğrudan gözlem ve görüşme olmadığında araştırma problemiyle ilgili yazılı ve görsel materyaller araştırmada kullanılabilir. Dolayısıyla belgesel tarama tek başına bir araştırma modeli olabilir (Yıldırım ve Şimşek, 2013). İşbu model, doküman incelemesi ve belgesel gözlem olarak da adlandırılmaktadır.

Araştırmanın Evren ve Örneklemi: Araştırmanın evrenini, ülkemizde hizmet veren tüm kadın voleybol spor kulüpleri oluşturmaktadır. Uluslararası Profesyonel Voleybol Kulüpleri Birliği (ACPV), Uluslararası Voleybol Federasyonu (FIVB) ve Avrupa Voleybol Konfederasyonunun (CEV) resmi web sayfalarında yayımlanan 2019 yılı kulüpler sıralamalarında Eczacıbaşı VitrA Spor Kulübünün ilk 5 (beş) spor kulübü içerisinde yer alması çalışmanın çıkış noktasını meydana getirmiştir.

Kulübün en sık kullandığı kurumsal sosyal medya platformları olan Facebook, Twitter, Instagram ve YouTube hesaplarının açılış tarihlerinden araştırmacı tarafından en son inceleme yapılan 19 Mayıs 2020 tarihine kadar olan süreç araştırmanın örneklemini oluşturmuştur.

Verilerin Toplanması ve Analizi: Araştırmanın verileri, belirtilen tarihler aralığında Eczacıbaşı VitrA Spor Kulübünün sosyal medya hesaplarındaki dokümanların incelenmesiyle elde edilmiştir. Dokümanlar literatürde fiziksel veri olarak da adlandırılmakta ve materyal kültürünün önemli bir parçası olarak kabul edilmektedir. Dokümanlar bilgisayar veya internet üzerinden elektronik formatta da incelenebilmektedir (Başve Akturan, 2013).

Doküman incelemesi tekniğiyle ulaşılan verilerin analizinde betimsel analiz yöntemi kullanılmıştır. Betimsel analiz yönteminde verilere sahip olunmadan önce belirli temalar oluşturulur. Söz konusu temalar, araştırmacı tarafından ya da yapılan başka bir araştırmanın boyutları temel alınarak geliştirilebilir. Akabinde ise elde edilen veriler; daha evvel belirlenen temalara uygun bir şekilde yerleştirilir, özetlenir ve yorumlanır. Amaç, elde edilen bulguları düzenlenmiş ve yorumlanmış biçimde okuyucuya aktarmaktır (Yıldırım ve Şimşek, 2013).

$\mathrm{Bu}$ araştırmada öncelikle, literatürde incelenen çalışmalar da göz önünde bulundurularak başarı, görünüm, hesap içeriği, paylaşım türü ve karşılaştırma olmak üzere 5 (beş) tema belirlenmiştir. Ardından ulaşılan veriler, oluşturulan temalara uygun bir şekilde işlenmiş; son olarak da tanımlanmış ve yorumlanmıştır.

Belirlenen temalara ilişkin bilgiler, araştırmada oluşturulan çerçevenin daha kolay anlaşılabilmesi açısından aşağıda sunulmuştur. 
1. Başart: Kulübün kuruluş tarihi ile ulusal ve uluslararası şampiyonluklarına ilişkin bilgiler içermektedir.

2. Görünüm: Kulübün sosyal medya hesaplarındaki profil adları, logosu, tanıtım görseli/videosu, iletişim bilgileri, kurumsal web adresi ve diğer sosyal medya hesap uzantılarına ilişkin değişkenler ele alınmıştır.

3. Hesap İçeriğgi: Kulübün sosyal medya hesaplarının açılış tarihlerinden 19 Mayıs 2020 tarihine kadarki takipçi sayısı, takip sayısı, toplam beğeni sayısı, toplam gönderi/paylaşım sayısı, paylaşım sıklığı, toplam görüntülenme/izlenme sayısı, toplam yorum sayısı ve yer bildirimi ile ilgili sayfa içeriğine ilişkin değişkenler ele alınmıştır.

4. Paylaşım Türü: Kulübün sosyal medya hesapları üzerinden hangi tür paylaşımlar yapıldığı ile ilgili bilgiler içermektedir.

5. Karşılaştırma: 2019 FIVB Kadınlar Dünya Kulüpler Şampiyonası̉nda ilk 5 (beş) içerisinde yer alan spor kulüplerinin sosyal medya hesapları açılış tarihlerinden 19 Mayıs 2020 tarihine kadarki abone/ takipçi sayıları, toplam beğeni sayıları ve toplam paylaşım/tweet sayılarına göre karşılaştırılmasına ilişkin değişkenler ele alınmaktadır.

Yukarıda verilen yer alan kavramlardan yola çıkılarak kodlama cetveli çalışmada uygulanabilir hâle getirilmiştir.

Patton’a (2014) göre nitel araştırmaların inanılırlığı birbiri ile ilişkili üç farklı araştırma ögesine bağlıdır. Bunlar: araştırmacının inanılırlığı, nitel araştırmanın değerine olan inanç ve titiz çalışmadır. $\mathrm{Bu}$ araştırmada elde edilen bulguların iç ve dış geçerlilik ile güvenirlilik problemlerini aşmak için literatürde yer alan benzer çalışmalar ile bu çalışmaların araştırma metotları titizlikle incelenmiştir. İnceleme sonucunda çalışmaya uygun olan değişkenler araştırmacı tarafından araştırmaya dâhil edilerek temalar altında sınıflandırılmıştır.

\section{BULGULAR}

Eczacıbaşı VitrA Spor Kulübünün kurumsal iletişim aracı olarak kullandığı sosyal medya platformuna ait resmi hesapları olan Facebook, Twitter, Instagram ve YouTube üzerinden elde edilen veriler belirlenen temalara işlenerek aşağıda sunulmuştur.

Başarıtemasıaltında,Eczacıbaşı VitrA Spor Kulübünün kuruluştarihi, Türkiye altyapışampiyonlukları, Türkiye lig şampiyonlukları, Türkiye lig kupası şampiyonlukları, Avrupa şampiyonluğu ve dünya şampiyonlukları ile ilgili istatistiksel veriler yer almakta ve Tablo 1'de gösterilmektedir. 
Tablo 1. Eczacıbaşı VitrA Spor Kulübü başarılarına ilişkin bulgular

\begin{tabular}{lcccccc}
\hline Kulüp & $\begin{array}{c}\text { Kuruluș } \\
\text { Tarihi }\end{array}$ & $\begin{array}{c}\text { Türkiye Altyapı } \\
\text { Şampiyonluğu }\end{array}$ & $\begin{array}{c}\text { Türkiye Lig } \\
\text { Şampiyonluğu }\end{array}$ & $\begin{array}{c}\text { Türkiye } \\
\text { Lig Kupası } \\
\text { Şampiyonluğu }\end{array}$ & $\begin{array}{c}\text { Avrupa } \\
\text { Şampiyonluğu }\end{array}$ & $\begin{array}{c}\text { Dünya } \\
\text { Şampiyonluğu }\end{array}$ \\
\hline $\begin{array}{l}\text { Eczacıbașı } \\
\text { VitrA Spor }\end{array}$ & 1966 & $23 \mathrm{kez}$ & $28 \mathrm{kez}$ & $9 \mathrm{kez}$ & $1 \mathrm{kez}$ & $2 \mathrm{kez}$ \\
Kulübü & & & & & & \\
\hline
\end{tabular}

Tablo 1 incelendiğinde, 1966 yılında kurulup 1968 yılında voleybol ligine katılan Eczacıbaşı VitrA Spor Kulübünün 23 kez Türkiye altyapı, 28 kez Türkiye ligi, 9 kez Türkiye kupası, 1 kez Avrupa kupası ve 2 kez dünya kupası şampiyonlukları elde ettiği görülmektedir.

Görünüm teması altında, Eczacıbaşı VitrA Spor Kulübünün sosyal medya hesaplarındaki profil adı, logosu, tanıtım görseli/videosu, iletişim bilgileri, kurumsal web adresi ve diğer sosyal medya hesap uzantıları ile ilgili bulgular yer almakta ve Tablo 2'de gösterilmektedir.

Tablo 2. Eczacıbaşı VitrA Spor Kulübü sosyal medya hesaplarının görünümlerine ilişkin bulgular

\begin{tabular}{lcccccc}
\hline $\begin{array}{l}\text { Sosyal Medya } \\
\text { Uygulaması }\end{array}$ & Profil Adı & Logo & $\begin{array}{c}\text { Tanıtım } \\
\text { Görseli } / \\
\text { Video }\end{array}$ & $\begin{array}{c}\text { İletişim } \\
\text { Bilgileri }\end{array}$ & $\begin{array}{c}\text { Kurumsal } \\
\text { Web Adresi }\end{array}$ & $\begin{array}{c}\text { Diğer Hesap } \\
\text { Uzantıları }\end{array}$ \\
\hline Facebook & @EczacibasiSporKulubu & Var & Var & Var & Var & Yok \\
Twitter & @EczacibasivitrA & Var & Var & Yok & Var & Yok \\
Instagram & eczacibasisporkulubu & Var & Var & Yok & Yok & Yok \\
YouTube & EczacibasiSK & Var & Var & Yok & Yok & Var \\
\hline
\end{tabular}

Tablo 2 incelendiğinde, Eczacıbaşı VitrA Spor Kulübü sosyal medya hesapları olan Facebook, Twitter, Instagram ve YouTube sayfalarında profil isimleri farklı olup logo ve tanıtım görseli/videosu yer almaktadır. Kulüp iletişim bilgileri sadece Facebook hesabında bulunurken kulübün kurumsal web adresinin sadece Facebook ve Twitter hesaplarında, diğer hesap uzantılarının (sosyal medya hesapları) ise yalnızca YouTube sayfasında yer aldığı görülmektedir.

Hesap içeriği teması altında, Eczacıbaşı VitrA Spor Kulübünün sosyal medya hesaplarının açılış tarihlerinden 19 Mayıs 2020 tarihine kadarki takipçi sayısı, takip sayısı, toplam beğeni sayısı, toplam gönderi / paylaşım sayısı, paylaşım sıklığı, toplam görüntülenme/ izlenme sayısı, toplam yorum sayısı ve yer bildirimi ile ilgili sayfa içeriğine ait bulgular yer almakta ve Tablo 3’te gösterilmektedir. 
Tablo 3. Eczacıbaşı VitrA Spor Kulübü sosyal medya hesaplarının içeriklerine ilişkin bulgular

\begin{tabular}{|c|c|c|c|c|}
\hline Değişkenler & Facebook & Twitter & Instagram & YouTube \\
\hline Hesap Açma Yılı & 2012 & 2012 & Bilinmiyor & 2012 \\
\hline Takipçi Sayısı & $45,4 \mathrm{~B}$ & $21,6 \mathrm{~B}$ & $98,7 \mathrm{~B}$ & $4,66 \mathrm{~B}$ \\
\hline Takip Sayısı & Bilinmiyor & 42 & 53 & Bilinmiyor \\
\hline Toplam Beğeni Sayısı & $44,9 \mathrm{~B}$ & Bilinmiyor & Bilinmiyor & Bilinmiyor \\
\hline $\begin{array}{l}\text { Toplam Gönderi / } \\
\text { Paylaşım Sayısı }\end{array}$ & Bilinmiyor & $10,9 \mathrm{~B}$ & $5,4 \mathrm{~B}$ & 179 \\
\hline Paylaşım Sıklığı & Bilinmiyor & $\begin{array}{c}\text { Ortalama Her Gün } \\
\text { En Az Bir Paylaşım } \\
\text { (Fotoğraf, Video) }\end{array}$ & $\begin{array}{c}\text { Ortalama Her Gün } \\
\text { En Az Bir Paylaşım } \\
\text { (Fotoğraf, Video) }\end{array}$ & $\begin{array}{c}\text { Ortalama } 20 \text { Günde } \\
\text { En Az } 1 \text { Video }\end{array}$ \\
\hline $\begin{array}{l}\text { Toplam } \\
\text { Görüntülenme / } \\
\text { İzlenme Sayısı }\end{array}$ & Bilinmiyor & Bilinmiyor & Bilinmiyor & $722,2 \mathrm{~B}$ \\
\hline Toplam Yorum Sayısı & Bilinmiyor & Bilinmiyor & Bilinmiyor & Bilinmiyor \\
\hline Yer Bildirimi & Bilinmiyor & Bilinmiyor & Bilinmiyor & Yok \\
\hline
\end{tabular}

Tablo 3 incelendiğinde, Instagram uygulamasının bu özelliği olmadığından hesap açma yılı bilinmemekte olup diğer hesapların 2012'de açıldığı görülmektedir. Takipçi sayısına göre bakıldığında 98,7B ile ilk sırada Instagram yer alırken onu 45,4B ile Facebook, 21,6B ile Twitter ve 4,66B ile YouTube uygulamaları takip etmektedir. Facebook ve YouTube'da takip ettikleri sayfaların sayısı gizli olduğundan bilinmezken Twitter'da 42, Instagram'da 53 sayfayı takip ettikleri görülmektedir. Twitter, Instagram ve YouTube hesaplarının toplam beğeni sayısı bilinmezken Facebook'ta 44,9B olduğu görülmektedir. Facebook’taki toplam gönderi/paylaşım sayısı bilinmezken Twitter'da 10,9B, Instagram'da 5,4B, YouTube’da 179 olduğu görülmektedir. Paylaşım sıklığına bakıldı̆̆ında Twitter ve Instagram'da "ortalama her gün en az bir paylaşım (fotoğraf, video)", YouTube hesabında "ortalama 20 günde en az 1 paylaşım” yapıldığı belirlenmiş olup Facebook’ta bu sayı bilinmemektedir. YouTube hesabında 722,2B görüntülenme/izlenme sayısı belirlenirken Facebook, Twitter ve Instagram hesaplarında bilinmemektedir. Sosyal medya hesaplarında gerçekleşen toplam yorum sayısı bilinmemektedir. Yer bildirimi faaliyetleri Facebook, Twitter ve Instagram hesaplarında bilinmezken YouTube’da yer bildirimi yapılmamıștır.

Yukarıda bahsi geçen "Bilinmiyor” kısımlarına ait veriler Eczacıbaşı VitrA Spor Kulübü sosyal medya sorumlularından e-posta yoluyla istenmiş olup zaman, iş yoğunluğu, pandemi vb. sorunlardan dolayı olumsuz geri dönüş alınmıştır. Dolayısıyla bu bölümlere ait bilgiler tabloda yer almamıştır.

Bu tema ve diğer temalar altındaki "B” ifadeleri 1000 (bin) sayısına karşılık gelmekte olup “yaklaşık değer” olarak ifade edilmektedir.

Paylaşım türü teması altında, Temel’in (2019) çalışmasında yer alan "sosyal medyayı kullanım amaçları" maddelerine araştırmacı tarafından kulübün sosyal medya hesapları üzerinden 
gerçekleştirilen paylaşımların içeriklerinin incelenmesiyle bazı eklemeler yapılarak elde edilen bulgular yer almakta ve Tablo 4’te gösterilmektedir.

Tablo 4. Eczacıbaşı VitrA Spor Kulübü sosyal medya hesaplarındaki paylaşım türlerine ilişkin bulgular

\begin{tabular}{lllll}
\hline Değişkenler & Facebook & Twitter & Instagram & YouTube \\
\hline Resmi Açıklamalar & + & + & + & + \\
Haber ve Duyurular & + & + & + & + \\
Etkinlik Bilgileri & + & + & + & + \\
Maç Skorları & + & + & + & + \\
Antrenman Fotoğraf ve Videoları & + & + & + & + \\
Maç Fotoğraf ve Videoları & + & + & + & + \\
Oyuncular Hakkında Bilgi/Fotoğraf/Video/Söyleși & + & + & + & + \\
ve Röportajlar & + & + & + & + \\
Özel Gün / Taziye / Kutlama /Tebrik Mesajları & + & + & + & yok \\
Anlık İletiler & + & + & yok & + \\
Lisanslı Ürün Tanıtımı ve Satış Yönlendirme & + & yok & + & + \\
Bilet Satışı Yönlendirme & yok & + & + & yok \\
Çekiliş, Hediye, Promosyonlar & + & + & yok \\
Taraftar ve Sporculara Yönelik Yarışmalar & + & yok & yok \\
Taraftar Anketleri & yok & yok & + & yok \\
Taraftar Kartları Tanıtımı ve Satış Yönlendirme & yok & + & + \\
Spor Okulları Hakkında Bilgiler & + & + & + & + \\
Sosyal Sorumluluk Projeleri & + & + & + & + \\
Sponsor(luk) Paylaşımları & + & & + & + \\
\hline
\end{tabular}

Tablo 4 incelendiğinde, resmi açıklamalar, haber ve duyurular, etkinlik bilgileri, maç skorları, antrenman fotoğraf ve videoları, maç fotoğraf ve videoları, oyuncular hakkında bilgi/fotoğraf/video/ söyleşi/röportajlar, özel gün/taziye/kutlama/tebrik mesajları, anlık iletiler, lisanslı ürün tanıtımı ve satış yönlendirme, çekiliş, hediye ve promosyonlar, taraftar ve sporculara yönelik yarışmalar, sosyal sorumluluk projeleri ve sponsor(luk)lar ile ilgili paylaşımların her sosyal medya hesabında yapıldığı görülmektedir. Ancak spor okulları hakkında bilgi Facebook, Twitter ve Instagram sayfalarında yer alırken YouTube sayfasında yer almamaktadır. Bunun yanı sıra bilet satışı yönlendirme, taraftar anketleri, taraftar kartları tanıtımı ve satış yönlendirme gibi faaliyetlerin paylaşımının hiçbir sosyal medya hesabı üzerinden gerçekleştirilmediği belirlenmiştir.

Karşılaştırma teması altında, 2019 FIVB Kadınlar Dünya Kulüpler Şampiyonası’nda ilk 5 içerisinde yer alan spor kulüplerinin hesap açma yılı, abone/takipçi sayısı, toplam beğeni sayısı ve toplam paylaşım/tweet sayısı gibi sosyal medya hesap içeriklerine ait değişkenlerle ilgili bulgular yer almakta ve Tablo 5’te gösterilmektedir. 
Tablo 5. 2019 FIVB Kadınlar Dünya Kulüpler Şampiyonası’nda ilk 5 içerisinde yer alan spor kulüplerinin sosyal medya hesap içeriklerine göre karşılaştırılmasına ilişkin bulgular

\begin{tabular}{|c|c|c|c|c|c|}
\hline Kulüp & Değișkenler & Facebook & Twitter & Instagram & YouTube \\
\hline \multirow{4}{*}{$\begin{array}{l}\text { Eczacıbaşı VitrA } \\
\text { Spor Kulübü }\end{array}$} & Hesap Açma Yllı & 2012 & 2012 & - & 2012 \\
\hline & Abone/Takipçi Sayısı & $45,4 \mathrm{~B}$ & $21,6 \mathrm{~B}$ & $98,7 \mathrm{~B}$ & $4,66 \mathrm{~B}$ \\
\hline & Toplam Beğeni Sayısı & $44,9 \mathrm{~B}$ & - & - & - \\
\hline & Toplam Paylaşım/Tweet & - & $10,9 \mathrm{~B}$ & $5,4 \mathrm{~B}$ & 179 Video \\
\hline \multirow{4}{*}{$\begin{array}{l}\text { Igor Gorgonzola } \\
\text { Novara }\end{array}$} & Hesap Açma Yilı & 2012 & 2012 & - & 2014 \\
\hline & Abone/Takipçi Sayısı & $28,7 \mathrm{~B}$ & $5,7 \mathrm{~B}$ & $31,9 \mathrm{~B}$ & 435 \\
\hline & Toplam Beğeni Sayısı & $28 \mathrm{~B}$ & - & - & - \\
\hline & Toplam Paylaşım/Tweet & - & $5,4 \mathrm{~B}$ & $2 \mathrm{~B}$ & 41 Video \\
\hline \multirow{4}{*}{$\begin{array}{l}\text { Imoco Volley } \\
\text { Conegliano }\end{array}$} & Hesap Açma Yılı & 2012 & 2012 & - & 2013 \\
\hline & Abone/Takipçi Sayısı & $42,8 \mathrm{~B}$ & $8 \mathrm{~B}$ & $45 \mathrm{~B}$ & $1,6 \mathrm{~B}$ \\
\hline & Toplam Beğeni Sayısı & $41 \mathrm{~B}$ & - & - & - \\
\hline & Toplam Paylaşım/Tweet & - & $5 \mathrm{~B}$ & $2,4 \mathrm{~B}$ & 184 Video \\
\hline \multirow{4}{*}{ Itambe Minas } & Hesap Açma Yılı & 2018 & 2009 & - & 2012 \\
\hline & Abone/Takipçi Sayısı & $14 \mathrm{~B}$ & $41 \mathrm{~B}$ & $51 \mathrm{~B}$ & $17,8 \mathrm{~B}$ \\
\hline & Toplam Beğeni Sayısı & $13,6 \mathrm{~B}$ & - & - & - \\
\hline & Toplam Paylaşım/Tweet & - & $32,6 \mathrm{~B}$ & 669 & 317 Video \\
\hline \multirow{4}{*}{ Vakıfbank } & Hesap Açma Yllı & 2011 & 2012 & - & 2016 \\
\hline & Abone/Takipçi Sayısı & $64,6 \mathrm{~B}$ & $24,6 \mathrm{~B}$ & $108 \mathrm{~B}$ & $8,6 \mathrm{~B}$ \\
\hline & Toplam Beğeni Sayısı & $64 \mathrm{~B}$ & - & - & - \\
\hline & Toplam Paylaşım/Tweet & - & $6,6 \mathrm{~B}$ & $3,9 \mathrm{~B}$ & 143 Video \\
\hline
\end{tabular}

Tablo 5 hesap açma yılı değişkenine göre incelendiğinde Eczacıbaşı VitrA Spor Kulübünün bütün sosyal medya hesaplarını 2012 yılında açtı̆̆ı gözlenmektedir. Kulüplerin hesap açma yılları birbirlerine yakın olmakla birlikte Itambe Minas’ın Facebook hesabını rakiplerinden çok geç (2018) ve Twitter hesabını rakiplerinden erken (2009) açtığı göze çarpmaktadır. Instagram uygulamasında bu özellik olmadığı için kulüplerin Instagram hesaplarının ne zaman açıldığı bilinmemektedir. Abone/takipçi sayısı değişkenine göre incelendiğinde Eczacıbaşı VitrA Spor Kulübünün Facebook’ta 45,4B takipçi ile 2., Twitter'da 21,6B takipçi ile 3., Instagram'da 98,7B takipçi ile 2. ve YouTube'da 4,66B takipçi ile 3. sırada yer aldığına ulaşılmaktadır. Toplam beğeni sayısı değişkenine göre incelendiğinde Eczacıbaşı VitrA Spor Kulübünün Facebook’ta 44,9B beğeni ile 2. sırada olduğu belirlenmektedir. Twitter, Instagram ve YouTube hesaplarının toplam beğeni sayısı, uygulamalarda bu özellik olmadı̆̆ için bilinmemektedir. Toplam paylaşım/tweet sayısı değişkenine göre incelendiğinde Eczacıbaşı VitrA Spor Kulübü Twitter hesabında yaptığ 10,9B paylaşım ile 2., Instagram hesabında yaptığı 5,4B paylaşım ile 1., YouTube hesabında yaptığ 179 paylaşım ile 3. sırada yer almaktadır. Facebook uygulamasında bu özellik olmadığı için paylaşım/tweet sayısı bilinmemektedir. 


\section{TARTIŞMA VE SONUÇ}

İletişim teknolojilerinde yaşanan gelişmeler düşünüldügünde iletişimin günümüzde önlenemez bir ivme ile yükselişte olduğu görülmektedir. Televizyon, gazete, dergi ve radyo gibi geleneksel medya araçlarının içerisine sanal dünyalar, sosyal ağlar gibi sosyal medya ortam ve araçları yeni medya olarak eklenmiştir. Sosyal ağlar, ülkemizde ve dünyada paydaşların anında bilgi edinmelerine ve birbirleriyle etkileşimde bulunmalarına imkân tanımaktadır. Bu nedenle spor kulüplerinin paydaşlarını tanımak, onların istek ve şikâyetlerini anlamak, bu doğrultuda yönetim stratejileri oluşturarak sonuçlarını onlara aktarıp anında geri bildirim almak adına yeni medya olarak tanımlanan sosyal medya içerisinde var olmaları gerekmektedir (Karakoç, 2019).

Araştırmanın bu bölümünde, elde edilen bulgular yorumlanarak benzer çalışmalar ile birlikte değerlendirilmiş ve ortaya çıkan sonuçlar aşağıda sunulmuştur. Literatür taraması sonucunda benzer çalışmalara ait bazı alt başlıklara ilişkin karşılaştırma yapılabilirken çalışmanın alanında ilk olması sebebiyle bazı alt başlıklar ile ilgili karşılaştırma yapılamamıştır.

Eczacıbaşı VitrA Spor Kulübü, Voleybol Kadınlar 1. Ligi’nde en fazla şampiyonluk elde eden ve Türk kadın voleybolunda ilk Avrupa kupası şampiyonluğu yaşayan kulüptür. Bu yönüyle Türkiye’nin en önemli ve değerli kadın voleybol spor kulüplerinden biri olduğu görülmektedir. Söz konusu bilgilerden yola çıkılarak gençlere bu spor dalının sevdirilmesinde, elde ettiği başarı hikâyeleri ile kadınların spora olan sevgisinin ve toplumdaki saygınlıklarının arttırılmasında önemli rol oynadığı, Türk kadın voleyboluna ve ülke başarısına büyük katkı sağladığı düşünülmektedir.

Görünüm temasına ait bulgular değerlendirildiğinde (Tablo 2), resmi sosyal medya hesapları olan Facebook, Twitter, Instagram ve YouTube sayfalarında logo ve tanıtım görseli/video kullandıkları gözlemlenmiştir. Karakoç (2019), Türkiye'deki belediyelerin sosyal medya hesapları üzerine yaptığı araştırmada, kurumların, hesaplarında logo, resim, video vb. tanıtım içerikleri gibi kurumsal davranışları ürettikleri her türlü çıktıyı, var oldukları ve paydaşlarıyla etkileşime girdikleri her alana entegre etmeleri gerektiğini ifade etmektedir. Karakoç’un (2019) çalışmasından da hareketle, Eczacıbaşı VitrA Spor Kulübünün sosyal medya hesaplarında logo ve tanıtım görseli bulunmasının kulübün kurumsal kimliğinin sağlamlaşması adına olumlu bir durum olduğu sonucuna ulaşılabilir.

Kulüp iletişim bilgilerinin sadece Facebook, kurumsal web adresinin sadece Facebook ve Twitter, diğer sosyal medya hesap uzantılarının ise yalnızca YouTube hesabında olmasının kurumsallaşma ve erişilebilirlik açısından büyük bir dezavantaj yarattığı söylenebilir. Kocabaş (2016), Arçelik ve Bosch markalarının sosyal medya hesaplarını incelediği çalışmada, çağrı merkezi ve kurumun web sayfasına yönlendirici link gibi bilgilerin sosyal medya sayfalarında yer almamasını, sosyal medya üzerinde tam anlamıyla kurumsallığı yakalayamamanın bir göstergesi olarak ifade etmektedir. Bu anlamda, iletişim bilgileri, kurumsal web adresi ve diğer hesap uzantılarına ait bilgilerin kulübün tüm sosyal medya hesaplarında aktif olarak yer alması, Eczacıbaşı VitrA Spor Kulübünün sosyal medyada kurumsal bir görüntü sergilemesine katkı sağlayacaktır. Ayrıca bu durumun taraftarlar, finansal kuruluşlar (sponsorlar ya da sponsor adayları), yayıncı kuruluşlar, ulusal ve uluslararası 
spor kuruluşları gibi paydaşların her platformda kulübe ulaşması ve kulüp hakkında bilgi edinmesi açısından büyük önem arz ettiği düşünülmektedir.

Kulübün incelenen sosyal medya hesaplarında kullandığı profil isimlerinin farklı olduğu göze çarpmaktadır. Bu durumun kullanım kolaylığı ve paydaşların kulübe erişebilirliği açısından olumsuzluk yaratabileceği düşünülmektedir. Tek bir profil isminin belirlenip tüm sosyal medya hesaplarında bu ismin kullanılmasının kulübün kurumsal kimliğini pekiştireceği öngörülmektedir.

Hesap içeriği temasına ait bulgular (Tablo 3) toplam beğeni sayısı, toplam gönderi/paylaşım sayısı, paylaşım sıklığı ve toplam görüntülenme/izlenme sayısı açısından incelendiğinde sosyal medya hesaplarının çok aktif kullanıldığı görülmektedir. Ayrıca çoğu ulusal ve uluslararası federasyonun/ kuruluşun 2019 yılında resmi web sayfalarında yayımladıkları puan cetvellerine göre ilk beş sırada yer alan kadın voleybol kulüplerinin sosyal medya hesapları arasında, yukarıda belirtilen değişkenler göz önüne alındığında Avrupa ve dünyada ilk üç içerisinde yer aldığı sonucuna varılmıştır.

Gerçekleştirilen faaliyetlerde yer bildirimi yapılmamasının, taraftarı/sponsoru oldukları takımın nerede olduğunu görmek ya da belirtmek isteyen taraftarlar/sponsorlar açısından bir eksiklik olacağı düşünülmektedir.

Paylaşım türü temasına ait bulgular değerlendirildiğinde (Tablo 4), resmi açıklamalar, haber ve duyurular, etkinlik bilgileri, maç skorları, antrenman fotoğraf ve videoları, maç fotoğraf ve videoları, oyuncular hakkında bilgi/fotoğraf/video/söyleşi/röportajlar, özel gün/taziye/kutlama/tebrik mesajları, anlık iletiler, lisanslı ürün tanıtımı ve satış yönlendirme, çekiliş, hediye ve promosyonlar, taraftar ve sporculara yönelik yarışmalar, sosyal sorumluluk projeleri ve sponsor(luk)lar ile ilgili paylaşımların sosyal medya hesapları üzerinden çok aktif bir şekilde icra edildiği görülmektedir. Lisanslı ürün tanıtımı ve satış yönlendirme, çekiliş/hediye/promosyon, taraftar ve sporculara yönelik yarışmalar, spor okulları hakkında bilgi, sosyal sorumluluk projeleri ve sponsor(luk) faaliyetleri gibi konularla ilgili daha az paylaşım yapıldığı belirlenmiştir. Bu durumun meydana gelmesinde zaman/ maliyet gibi kısıtlamalar ile sezon başı ve sonu gibi dönemlerin etkili olduğu söylenebilir.

Bilet satışı yönlendirme, taraftar anketleri, taraftar kartları tanıtımı ve satış yönlendirme gibi faaliyetlerin hiçbir sosyal medya hesabı üzerinden paylaşımının gerçekleştirilmemesi kurumsal açıdan büyük bir eksiklik olarak değerlendirilebilir. Katırcı ve Uztuğ (2009), spor kulüplerinde iletişim yönetimini inceledikleri çalışmada, stadyumlarından gelir elde etmekten daha fazla bilet satışına kadar birçok farklı gelir kanalını oluşturmak için paydaşlarla kişisel bir ilişki kurmanın ve onlarda memnuniyet oluşturarak satın alma davranışının tekrarlanmasını sağlamanın önemli olduğunu belirtmektedirler. Bunun da spor kulüplerinin taraftarlarıyla daha kişisel bir ilişki kurarak veri tabanı oluşturması ile gerçekleşebileceğini ifade etmektedirler. Dolayısıyla taraftarlara uygulanacak anketler sonucunda alınacak geri dönüşlerle taraftarlarla kulüp arasında kişisel bir ilişki kurulacağı, böylelikle de kulübün ekonomik yapısına katkı sağlanacağı düşünülmektedir. Yine taraftar kart oluşturma/ bilgilendirme/satış yönlendirme ile taraftarların biletleri hangi platformdan alacağı konularında, takımının resmi sosyal medya hesapları üzerinden görerek/tıklayarak ulaşmasının taraftar açısından daha güven verici bir durum olduğu düşünülmektedir. 
Spor okulları hakkında bilgi Facebook, Twitter ve Instagram sayfalarında mevcutken YouTube sayfasında yer almamaktadır. Spor okullarında gerçekleştirilen voleybol eğitim/maç videolarının kulübün YouTube hesabında yer almasının çocuğunun/sporcusunun durumunu ve gelişimini gözlemlemek isteyen veliler/antrenörler açısından önem arz ettiği düşünülmektedir. Ayrıca söz konusu eğitim videolarının kulübün YouTube sayfasında yayımlanmasının kulüp adına etkili bir tanıtım stratejisi olabileceği, dolayısıyla bu videoların en kaliteli video paylaşım platformlarından biri olan YouTube'da paylaşılması gerektiği öne sürülmektedir.

Literatürde kadın voleybol kulübü karşılaştırma temasına ilişkin benzer bir çalışma olmadığı için 2019 FIVB Kadınlar Dünya Kulüpler Şampiyonası’nda ilk 5 (beş) sırada yer alan spor kulüplerinin sosyal medya hesapları; hesap açma yılı, takipçi sayısı, beğeni sayısı, paylaşım sayısı değişkenlerine göre (Tablo 5) değerlendirilerek yorumlanmıştır.

Dünyada 2004-2005 yılları arası Facebook, 2005-2006 yılları arası YouTube, 2006-2007 yılları arası Twitter ve 2010-2011 yılları arasında ise Instagram uygulaması kullanılmaya başlanmıştır. Sosyal medya hesaplarının kuruluş tarihlerine bakıldığında Eczacıbaşı VitrA, Vakıfbank, Igor Gorgonzola Novara ve Imoco Volley Conegliano ve Itambe Minas spor kulüplerinin sosyal medya mecrasına katılmada çok geç kaldıkları gözlemlenmektedir. Bu durumun nedeninin dijital dönüşümün sonucu oluşan yeni medya olgusunun bu kadar büyük bir kitleye ulaşarak etki sağlayacağını öngörememeleri olduğu söylenebilir.

Söz konusu beş kadın voleybol kulübü sosyal medyadaki takipçi, beğeni ve paylaşım sayıları açısından değerlendirildiğinde Eczacıbaşı VitrA Spor Kulübünün bazı alanlarda birinci ve ikinci olmakla birlikte her alanda ilk üç arasında yer aldığı sonucuna ulaşılmaktadır. Bu beş kulübün 2019 yılında dünyanın en başarılı kadın voleybol kulüpleri oldukları ve bünyelerinde geniş taraftar kitlelerini barındırdıkları göz önünde bulundurulduğunda bu veriler, Eczacıbaşı VitrA Spor Kulübünün kadın voleybolu dalında dünyada sosyal medyayı en aktif kullanan kulüplerden biri olduğu düşüncesini desteklemektedir.

Yukarıda açıklanan bilgiler ışığında, Eczacıbaşı VitrA Spor Kulübünün popüler sosyal medya hesaplarını kullanmaya karar vermesinde teknolojideki ilerlemeler ile oluşan yeni medya anlayışını benimsemesi ve taraftarları ile iletişim kurarak onlara ulaşma, taleplerini değerlendirme, reklam oluşturma ve marka imajını güçlendirme nedenlerinin etkili olduğu düşünülmektedir. Eczacıbaşı VitrA Spor Kulübünün etkin bir marka imajı oluşturması ve markasını taraftar zihninde sürekli kılması adına, aktif olarak kullandığ sosyal medya hesaplarında araştırmada eksiklik olarak belirtilen yönlerini geliştirerek taraftarlarıyla iki yönlü iletişim kurması gerektiği düşünülmektedir. Kulüp taraftarlarınca yapılan yorumlarda, kulübün sosyal medya yönetimi tarafından ilgili hesaplarda paylaşımlar yapıldığı fakat taraftarlarla diyalog kurulmadığı gözlemlenmiştir. Hâlbuki hedef kitle ile birlikte ortak değerler üreterek taraftar bağlılığını arttırma yöntem ve stratejileri geliştirmenin sıklıkla aktif olarak paylaşım gerçekleştirmekten çok daha önemli olduğu düşünülmektedir. Bu nedenle, taraftarlarda oluşturulacak pozitif yönde etki ile taraftarların bağlılıklarına, memnuniyetlerine, hesap yönetimi kalite algılarına, kulübe duyulan güvene, maçlara gitme ve bilet/ürün satın alma 
niyetlerine ve marka imajı hakkındaki görüşlerine yönelik taraftar tutumu oluşturulması büyük önem arz etmektedir.

Bu çalışmanın Eczacıbaşı VitrA Spor Kulübü ile diğer spor kulüpleri için sosyal medya yönetimi ve taraftarlarla etkileşim anlamında kaynak teşkil edeceği düşünülmektedir. Ayrıca spor kulüpleri ile ilgili gerçekleştirilecek araştırmalara 1şı tutmak ve spor kulüplerinin sosyal medya içerikleri ile bunları kullanım düzeyleri konusunda fikir oluşturmak açısından literatüre katkı sağlayacağı umulmaktadır.

\section{KAYNAKLAR}

Akyüz, O. (2017). Taraftarların çevrim içi alışverişe karşı tutumlarının incelenmesi: Süper Lig Futbol Kulüp Taraftarları Üzerine Bir Araştırma. Marmara Üniversitesi, Sağlık Bilimleri Enstitüsü, Yüksek Lisans Tezi, İstanbul.

Ayan Gürsoy, E. (2019). Kurumsal iletişimde yeni bir platform olarak sosyal medya kullanımı: İBB Örneği. Marmara Üniversitesi, Sosyal Bilimler Enstitüsü, Yüksek Lisans Tezi, İstanbul.

Barutçu, S. ve Tomaş, M. (2013). Sürdürülebilir sosyal medya pazarlaması ve sosyal medya pazarlaması etkinliğinin ölçümü. IUYD, 4(1), 5-23.

Baş, T. ve Akturan, U. (2013). Nitel araştırma yöntemleri: Nvivo ile nitel veri analizi, örnekleme, analiz, yorum (2. baskı). Ankara: Seçkin Yayıncılık.

Bat M. Digital platformda sosyal medyanın stratejik kurumsal iletişime etkisi. Ege Üniversitesi Sosyal Bilimler Enstitüsü, Doktora Tezi, 2012, İzmir.

Binns, S., Hamil, S., Holt, M., Michie, J., Ougton, C., Shailer, L. ve Wright, K. (2003). The state of the game: The corporate governance of football clubs 2003. London: Birkbeck University football governance research centre. Research Paper, 4, 2-6.

Fox, S. (2009). e-Riches 2.0: Next-Generation marketing, strategies for making millions online. New York, Amacom.

Herand, D. ve Çalışır, T. (2014). Kurum içi iletişimi geliştirmede software (yazılım) kullanımının rolü. Kafkas Üniversitesi İktisadi ve İdari Bilimler Fakültesi Dergisi, 5(8), 67-78.

Johan, M.R.M. ve Noor, A.Z.M. (2013). The role of corporate communication in building organization's corporate reputation: An exploratory analysis, Interdisciplinary Journal of Comtemporary Research in Business, 4(12), 1230-1240.

Kahraman, M. (2010). Sosyal medya 101: Pazarlamacılar için sosyal medyaya giriş. İstanbul: MediaCat.

Karakoç, H. (2019). Halkla ilişkiler aracı olarak sosyal medya kullanımı: Türkiye’deki Büyükşehir Belediyelerinin Sosyal Medya Hesapları Üzerine Bir Araştırma. Akdeniz Üniversitesi, Sosyal Bilimler Enstitüsü, Yüksek Lisans Tezi, Antalya.

Karasar, N. (2010). Bilimsel araştırma yöntemi (21. baskı). Ankara: Nobel.

Katırcı, H. ve Uztuğ, F. (2009) Spor kulüplerinde iletişim yönetimi: Türkiye Profesyonel Futbol Liglerinde Yer Alan Spor Kulüplerinin İletişim Uygulamalarına İlişkin Araştırma. Anadolu Üniversitesi Sosyal Bilimler Dergisi, 9(1), 149-168.

Kocabaş, İ. (2016). Halkla ilişkiler aracı olarak sosyal medya: Arçelik ve Bosch Markalarının Kurumsal Facebook ve Twitter Hesapları Üzerine Bir İnceleme. Selçuk İletişim, 9(2), 69-91.

Özçağlayan, M. (2012). Sosyal medya ve futbol. Futbol Gelişim Bülteni, 6, 63-67.

Özel, E.K. (2014). Çalışanların Twitter kullanımının kurum imajına etkisi: Türkiye’de Bir Anket Çalışması. Journal of Yasar University, 9(35), 6138-6158. 
Patton, M.Q. (2014). Nitel araştırma ve değerlendirme yöntemleri (çev.: M. Bütün ve S.B. Demir). Ankara: Pegem. Peltekoğlu, F.B. (2004). Halkla ilişkiler nedir? (3. baskı). İstanbul: Beta Yayınları.

Temel, A.S. (2019). Sosyal medya, spor ve spor pazarlamasi. Research Gate, 1-25.

Vural, Z.B.A. ve Bat, M. (2010). Yeni bir iletişim ortamı olarak sosyal medya: Ege Üniversitesi İletişim Fakültesine Yönelik Bir Araştırma. Journal of Yasar University, 20(5), 3348-3382.

Yamamoto, G. ve Şekeroğlu, Ö. (2014). Sosyal medya ve blog. İstanbul: Kriter Yayınları.

Yıldırım, A. ve Şimşek, H. (2013). Sosyal bilimlerde nitel araştırma yöntemleri. Ankara: Seçkin Yayıncılık. 